\title{
Global Discourses and National Reconstruction: the impact of globalization on curriculum policy
}

\author{
MARK PRIESTLEY \\ Institute of Education, University of Stirling
}

\begin{abstract}
Globalization has been widely discussed and much contested. It has been claimed that the process of globalization has impacted greatly on the capacity of the nation-state to formulate policy (e.g. Reich 1992). Globalization has been accompanied by a seemingly endless process of change within education. This process has assumed a worldwide character, as policies have migrated around the world; thus there have existed many similarities in terms of, for instance curriculum provision, or school governance, between New Zealand, Australia, the United Kingdom and the USA. This paper is concerned with the links between globalization and the process of change in one area of education, that is the development of national frameworks for curriculum and assessment.
\end{abstract}

\section{KEY WORDS}

globalization; curriculum; assessment; national; policy

\section{INTRODUCTION}

The last twenty years have witnessed what Levin (1998: 131) has described as a 'state of change' within the public education systems of the anglophone nations. In the words of Macedo:

educationally the decade of the 1980s can be best characterised by an overdose of education reform pollution controlled mostly by a conservative discourse that celebrates a language of management, competition, testing, choice and free enterprise (Macedo 1994: 137). 
This statement about the USA in the 1980s could be equally well applied to Britain, Australia and New Zealand, and extended to cover the 1990s.

According to many commentators this state of change has been a widespread if not global phenomenon (Brown and Lauder 1992; Whitty et al 1998). Levin (1998) has identified six separate but interlinked themes or discourses that have been common to school systems in many countries. These are:

1. The tendency for educational change to be framed in economic terms, for example the development of human resources.

2. Increasing criticism of education and training; this has been described elsewhere as 'discourses of derision' (Ball 1990).

3. The tendency to demand improvements without a concurrent increase in resources.

4. The promotion of education change through changes in governance.

5. A marketisation of education (or at least a thrust towards the development of quasi-markets).

6. An increased emphasis on standards, accountability and testing.

Edwards at al (1999) have noted the global nature of these tendencies, which they describe as 'policy migration', and which have been underpinned by neo-liberal discourses. According to Cox (1995: 39):

Neo-liberalism is transforming states from being buffers between external economic forces and the domestic economy into agencies for adapting domestic economies to the exigencies of the global economy.

Thus, while the common discourses described above are being determined by the need for states to respond to a common set of issues and forces, they can also be seen as helping to redefine the role 
and nature of the state. These discourses are being driven forward through the application of 'new managerialist' practices (Ball 1998), and have been alleged to be part of the processes of globalization.

However this is not the full picture with regard to global education change; while there has been a convergence in policy and practice throughout the anglophone nation-states, there has also existed a considerable heterogeneity, as local traditions and influences merge with global trends through a process of 'glocalization' (Green 1999: 55; also Dale 2000) to produce hybrid education systems that retain many distinctive features. As noted by Henry et al (1999: 86), 'globalization is not necessarily a homogenising force, but also provides considerable opportunities for heterogeneity of cultural tradition to exist side by side'. This is evidenced, for example, in the current trends in Britain for the establishment of denominational schools from a variety of faiths. Thus, globalization does not 'automatically result in a universalising of particular trends and perspectives,.... but witness(es) the affirmation of difference, of local, regional and ethnic identities' (Edwards and Usher 1997: 256).

A second key point rests in the fact that the need for states to respond to global, or at least to international, forces is not a new phenomenon. According to Dale (2000: 88):

Education systems, curricular categories and indeed the institution of the state itself, are the product of a world culture based upon central ideas of modernisation.

That said, globalization does represent a 'new and distinct shift in the relationship between state and supranational forces, and it has affected education profoundly and in a range of ways' (Dale 2000: 90).

It is therefore interesting to reflect on how the formulation and implementation of education policy has been affected by the impact of those global forces and tendencies that have come to be known collectively as globalization. The nature and extent of these are of 
course contested. However two things are clear, as has been set out in this introduction: first education in general has been subject to wide ranging and far reaching changes over the last two decades, and second there has been a general consensus that globalization has had an impact on education. This paper will explore the links between the process of globalization and the changes that continue to impact on a particular aspect of the education systems of anglophone countries: that aspect is the introduction and implementation of national frameworks for curriculum and assessment. In choosing this focus, I must necessarily neglect other fascinating and worthwhile aspects of the impact of globalization on education policy and systems. While it is without doubt interesting to digress into topics such as the nature of education quasi-markets, and specific policy issues within political parties, I have resisted this temptation. Consequently, these topics are dealt with in a general fashion where necessary, in order to support the arguments made about curriculum and assessment policy and reform.

The paper will first discuss the general nature of education change, before examining the nature and extent of globalization. Finally I will narrow the focus and examine the links that can be drawn between globalization and the widespread introduction of national frameworks for curriculum and assessment within the anglophone nations.

\section{CHANGES IN DISCOURSE, POLICY AND PRACTICE IN EDUCATION}

It goes without saying that many national education systems have undergone widespread and far reaching changes over the last couple of decades. These initiatives are remarkable in the similarities that pervade them, and exemplify the 'policy migration' identified by Edwards et al (1998). Curriculum and assessment are areas that have been subject to major reform, and in which it is possible to discern global trends or similarities. There are similarities between different 
national curricular systems in terms of structure (e.g. sequential levels and outcomes), in terms of the language that is used (e.g. attainment targets, strands) and in terms of the strong instrumental thrust that tends to permeate them (e.g. contributing to the future economic success of the national economy). Such curriculum and assessment changes have been accompanied by equally far-reaching changes in governance, for example the devolution of financial responsibility to schools, and the application of managerial principles to the profession of teaching. The situation regarding these 'rampant and remorseless' changes (Hargreaves 1994: 6) has been complex and even contradictory. The current education paradigm has been described by Bernstein as a 'new pedagogic Janus' which 'recontextualises and thus repositions within its own ideology, features of apparently oppositional discourses' (Bernstein 1990: 88). More needs to be said about these general trends.

First the education reforms have been characterised by a tendency of central governments to divest themselves of responsibility for day-today management of schools. Thus schools have had powers of financial management devolved to them. For instance in Britain the 1988 Education Reform Act introduced local financial management of schools, and in New Zealand the post Picot (Picot 1988) reforms laid out in Tomorrow's Schools (Department of Education 1988) delegated similar budgetary powers to the Boards of Trustees of schools; in this latter case, many schools were encouraged to opt for 'bulk funding'. In some cases this has been accompanied by a removal of a tier of local government, as has been the case with the virtual emasculation of the LEAs in Britain. These moves towards the apparent extension of local autonomy have been underpinned by strong neo-liberal ideologies, which have extolled the virtues of the free-market, although this begs the following question: to what extent do the reforms really represent the extension of local autonomy; do they merely delegate responsibility without real power? The answers to these questions are 
largely beyond the scope of this paper. However many would agree with O'Neill's comment (made in the context of New Zealand) that states now see themselves as 'an unnecessary interposition between consumers (students and parents) and providers (teachers)' (O'Neill 1996-1997: 129).

A second set of trends concerns the contrasting tendency for governments to assert central control over their education systems.

This is a worldwide move towards recentralising control through national curricula, testing, appraisal, policy formulation, profiling, auditing and the like, while giving the impression of decentralisation. (Smyth and Shacklock 1998: 20).

The curricular initiatives mentioned above, and moves towards performance-related pay in teaching (the failed and quickly abandoned Australian Advanced Skills Teacher scheme and the recent Threshold payments in England and Wales) are examples of this phenomenon. More will be said about curriculum reform in due course.

This process of managerialism (Clarke et al 1994; Codd 1999; Girwitz et al 1995; Helsby 1999) has led to a radical reconstruction of the work of teachers (Hargreaves 1994; Smyth and Shacklock 1998; Helsby 1999) as increases in technical knowledge have led to new and sophisticated methods of surveillance and control (Apple 1990; 1995; 1998; Ball 1997; Smyth and Shacklock 1998), and as teachers take responsibility for (but not power over) the achievement of prespecified organizational goals' (Helsby 1999: 30). It has been argued that teachers have been deprofessionalised; in many respects they have been reduced to the level of 'proletarianised' technicians delivering preset teacher proof curricula (Apple 1995), rather than becoming action researchers and professional developers of their own curricula, as was envisaged by many professionals during the 1970s and 1980s 
(Stenhouse 1975; Elliott 1998). Such 'muscular' (Smyth and Shacklock 1998: 194) and technical-rational managerial approaches have 'fostered within educational institutions a culture where trust is no longer taken to be the foundation of professional ethics' (Codd 1999: 45). The discipline of 'observing, measuring, recording and regulating' has led to a situation where individuals 'participate in their own subjection' (Gibson 1986: 132). In short, 'the shots are being called further and further away from what transpires in classrooms' (Smyth and Shacklock 1998: 2).

Accompanying these conflicting trends has been a shift in the discourses underpinning education (Blenkin et al 1992; Smyth and Shacklock 1998). There are two aspects to this tendency. First education has witnessed an influx of what Hood (1995: 105) has described as 'new managerial catchwords', which have become so extensive that they constitute a 'new global vocabulary'. Second, existing discourses have been subject to what Ball (1990) has termed 'discourses of derision'. This rhetoric of school failure has served to 'create a sense of unease about teaching and justified subsequent government attempts to reconstruct teachers' work (Helsby 1999: 24). In identifying many of these catchwords that have come to permeate education, Smyth and Shacklock (1998: 5) have used the analogy of a palimpsest - the expunging of one set of discourses and their replacement by a new vocabulary, which has its roots in the world of industry and commerce. This apparent marginalisation of established educational discourses, and their replacement by a competing set, is neatly summed up by Arnold (1996: 226):

Conspicuously absent .... is an engagement with traditional educational discourses - learning theory, curriculum theory, pedagogy and so forth - all seem be irrelevant to the re-formulation now underway. 
Terms like 'consumer', 'provider', 'accountability', 'appraisal' and 'performance' have crept into the educational lexicon as replacements (Smyth and Shacklock 1998: 35). Thus a legitimating discourse for the use of power is constructed, which marginalises the voice of teachers and produces an appearance of successful curriculum change' (Elliott 1998: 34).

\section{GLOBALIZATION: THE NATURE OF THE BEAST}

Many of the changes described above have been attributed to globalization. However there are two caveats to bear in mind before proceeding. First, it is important to appreciate that policy formulation and implementation are complex processes, which are subject to many 'hegemonic and counter-hegemonic' influences as well as to structural constraints (Smyth and Shacklock 1998: 28). While the pressure of globalisation undoubtedly contributes to these processes it must be viewed against a backdrop of competing interest groups both at the level of policy construction, and indeed at the implementation stage; teachers as agents can drastically subvert policies that have not been developed in consultation with them, and which they feel that they do not 'own' (Apple 1995; Kelly 1989; Smyth and Shacklock 1998). Second, the nature and scope of globalization has been disputed; it is therefore necessary to adequately define the phenomenon before establishing the extent to which current changes in education can be attributed to it.

Wiseman (1995: 5) has given a useful and fairly comprehensive definition of globalization. This is a:

contested trend towards more interdependent, local, national and transnational economies and societies, the expansion of international trade, investment, production and financial flows, the growing significance of regional trading blocs and trade agreements, more influential roles 
for international financial institutions and transnational corporations, far greater mobility of capital - particularly financial capital - and the overall spread of highly commodified and individualised economic, social and cultural relations into ever more spheres of human activity.

This is a definition with a heavy emphasis on economic factors, and one which captures the 'deregulated, marketised, governing at a distance' essence of government and administration that is coming to be a defining characteristic of the era of globalization (Smyth and Shacklock 1998: 16). As such, it provides clues as to the increasing emphasis within education in conditions of high modernity on the economic, the commercial, the vocational and the instrumental. Giddens has provided an alternative definition that focuses additionally on social relations. According to Giddens (1990: 64), globalization can be ... defined as the intensification of worldwide social relations that link distant localities in such a way that local happenings are shaped by events occurring many miles away, and vice versa. This is a dialectical process because such local happenings may move in an obverse direction from the very distanciated relations that shape them. Local transformation is as much a part of globalization as the lateral extension of social connections across time and space.

This is a highly relevant definition. While it hints at the homogenisation that has been alleged to be a feature of globalization, it also identifies the paradoxical nature of the process. Globalization is thus identified as a dialectical process, whereby local reactions to the phenomenon can also dictate policy directions. Together the two definitions are sufficient to encompass the main parameters of globalization. While it is without doubt a highly complex phenomenon, 
it is possible to discern two broad and apparently contradictory aspects to globalization; these are impacting on the nation state in general and upon education systems in particular.

On the one hand, globalization is widely claimed to have weakened the sovereignty of the nation state (e.g. Reich 1992). It has been claimed that the influence of supranational organizations such as the World Bank, the IMF and the OECD, of multinational corporations, and of transnational regional groupings such as the EC have contributed to a homogenisation of policy and discourse in many areas (Brown and Lauder 1996; Kumar 1992; Reich 1991; Smyth and Shacklock 1998).

This is worthy of closer investigation. Dale (1999) has employed a useful theoretical framework for analysing nature of states' policy responses to global trends. He has compared and contrasted traditional policy borrowing (where a policy is imported wholesale and applied to the new national context) and policy learning (where features of overseas policies are modified and selectively applied to the new context), with new homogenising tendencies which can be identified with globalization. While traditional forms of policy migration could be argued to be a feature of the rationality aspired to by modern states, Dale has pointed to the existence of new mechanisms for this that are more characteristic of globalization, and which have increased the tendencies towards policy migration. These mechanisms include harmonisation (as within the European Community), dissemination of 'best practice' (e.g. as in OECD reports such as Skilbeck 1990), and imposition (e.g. World Bank education loans). It seems likely that in the present context, this latter direct influence in the field of education remains limited. While developing nations may be subject to what Green (1999: 56) calls 'the direct jurisdiction of supra-national bodies over national education systems' through the imposition of policies in return for loans, the direct influence of these NGOs is relatively limited in the Anglophone states, where harmonisation tends to be confined still to economic matters. 
More significant have been the more indirect global pressures that have led to the Hayekian neo-liberal hegemony of market forces and the dominance of commercial discourses (as previously highlighted) within public welfare systems worldwide. Thus neo-liberalism has become to a large extent ' the only game in town' (Falk 1999: 127), a largely unquestioned and in many respects unquestionable orthodoxy. This process has been described by Cox (1996: 301) as:

a transnational process of consensus formation among the official caretakers of the global economy .. (which) .. generates consensual guidelines .. that are transmitted into the policymaking channels of national government and the big corporations.

Thus the undoubted economic pressures wrought by globalization and the concomitant reluctance of the new global elites to fund public systems, have led to a reduction or freezing of budgets in many cases (Levin 1998), and increased pressures to adopt neo-liberal cost cutting measures. The increased level of policy migration that has undoubtedly taken place between countries, has been at least in part symptomatic of these global processes, reflecting as it does the influence, albeit indirect, of the above mentioned bodies, as expressed through the dominant discourses.

Conversely these same pressures have led to what can be seen as both a reaction against and a feature of globalization, which has not resulted in complete convergence or homogenisation, nor indeed has it heralded the imminent demise of the nation state as a viable entity, as is claimed by the likes of Reich (1992). The situation is considerably more complex than this, as indicated by Marginson (1999: 25).

Globalization has not replaced the nation state, but has undermined the old nation state in certain respects, forcing it to change. 
Indeed there is some evidence that the pressures of globalization have led to a tightening, rather than a loss of state control in the sphere of education. As stated by Green (1999: 56):

as governments lose control over various levers on their national economies and cede absolute sovereignty in foreign affairs and defence, they frequently turn to education and training as two areas where they do still maintain control.

According to Halsey et al (1997: 159):

education remains one of the few areas of social policy over which national governments are able to assert decisive influence. In other words, educational policy has become an important test of statecraft where governments can demonstrate their power to improve the condition of everyday life.

There are two main stands to this tendency. First, fears about the loss of national sovereignty, and xenophobic 'forms of backlash chauvinism' (Henry et al 1999: 85) - reactions towards what Hall has described as an 'ethnic diaspora' (Hall, cited in Smyth and Shacklock 1998: 14) - have led to attempted reassertions of national and cultural identity. In some regions this has manifested itself a nationalist fragmentation (as in the Balkans); in others we have witnessed a resurgence of religious fundamentalism and/or militant, chauvinistic nationalism. In the case of education in Anglophone countries, such reactions have largely manifested themselves as cultural restorationism through curriculum prescription (Ball 1990; Goodson 1990, Hargreaves 1994; Lawton 1994), as forces of neo-conservatism have struggled to maintain national sovereignty, in the face of what has been seen as a legitimation crisis for national governments (Habermas 1976). Second, fears about the ability of nations to survive in the global market place have led governments to reassert their 
authority in areas that could have an impact on economic success; the development of a 'new vocationalism' in education (Brown and Lauder 1992), and the application of human capital theory to education systems (Apple 1998; Brown and Lauder 1992; Halsey et al 1997) are dimensions of this general trend.

It is therefore apparent that globalization has had a primary impact on public systems (via the influence of supranational bodies, and the penetration of their discourses and philosophies) and an indirect or secondary impact as nation-states struggle to come to terms with the conditions created by it. Giddens has noted this paradoxical element to globalization (1990: 73):

One aspect of the dialectical nature of globalization is the push and pull between tendencies inherent in the reflexivity of the system of states on the one hand, and the sovereignty of particular states on the other.

Thus the particularism of states and the interest groups that compose them - in the case of education, politicians and civil servants, academics and teachers, and even students - will continue to vie with global pressures in the formulation and implementation of policy.

The next section of this paper will explore the ways in which globalization has impacted on curriculum and assessment policy and provision in the anglophone states.

\section{THE CENTRALISATION OF CURRICULUM AND ASSESSMENT}

Recent curricular trends are manifestly moving anglophone states in the direction of central control over what is taught in schools, and how it is assessed. As a corollary of this, the term 'national curriculum' has come into vogue. Examples of this trend abound. The late 1980s heralded the introduction of a prescriptive National Curriculum in England and Wales. The early 1990s saw the 
introduction of parallel vocational tracks as the competency-based $G N V Q$ and $N V Q$ qualifications were introduced, and more recently English and Welsh schools have been faced with increasing prescription in the guise of the literacy and numeracy initiatives promulgated by New Labour. In New Zealand, National Party governments pushed through the New Zealand Curriculum Framework in 1993, shortly followed by the National Qualifications Framework, a unitary competency-based for all school and work-based qualifications (Irwin 1994; Smithers 1997). This latter framework has been subsequently adopted by South Africa (Jansen 1999), although interestingly it has been jettisoned in New Zealand in the face of teacher opposition, and replaced by the more flexible Achievement 2001 framework. In Australia, various states have introduced their own curriculum frameworks, for example Victoria's Curriculum and Standards Framework. In Scotland, the revised 5-14 Framework is currently exercising teachers' time and imagination. The United States has also been the site of similar trends; 'National standards, national curricula, national testing... are all being pushed for in the United States currently and are the subject of considerable controversy' (Apple 1999: 9).

This section of the paper will focus on the development of national frameworks for curriculum and assessment. As ever these trends are not simple (indeed they are often contradictory), and I shall attempt to disentangle them, while showing to what extent, if any they can be attributed to globalization. It is clear that many of the national frameworks, which have developed over the last few years, are part of wider global trends, and as such can be said to be part of the process of globalization. This is clear in the commonalities evident in terms of structure and language, which I will deal with shortly. However this is not the full picture. Goodson (1990: 220) has stated that in a general and worldwide sense: 
The globalization of economic life, and more particularly of communication, information and technology, all pose enormous challenges to the existing modes of control and operation of nation-states. In this sense, the pursuance of new centralised national curriculum might be seen more as a response of the more economically endangered among nations.

Goodson's statement neatly encapsulates the paradoxical nature of global curriculum policy. On the one hand he has identified the economic imperatives that are so evident in the technical-rational structures of curricula worldwide, in the instrumental language employed within these structures, and in the development of national frameworks for vocational education and training. On the other hand, he has identified the perceived threats to national sovereignty that have led to attempts at nation building through the institution of national curricula.

I shall argue that these trends in the development of centralised curriculum and assessment frameworks are part of the dialectical 'push and pull' nature of globalization observed by Giddens (1990). Such developments can be seen as a reaction against globalization, in that they represent a particularism in the face of what is seen in some quarters as the encroachment of global forces. They can also be seen as a response to globalization in that they represent attempts by national governments to make themselves more competitive on world markets through the medium of education.

The structure of and language used within various curriculum frameworks is indicative of the convergence or homogenisation of policy claimed by some commentators, and discussed earlier in the paper. The highly centralised National Curriculum introduced in England and Wales, and described by Beattie as of 'Kenneth Baker's essentially hierarchical or military vision of a chain of command from 
centre to periphery' (Beattie 1991: 39), is a good example of this trend. The model employs a linear structure, with sequential levels, and is articulated through the statement of outcomes, divided into subject areas, and further subdivided into strands. This pattern has been repeated in different countries' curricular offerings. Thus in New Zealand the Curriculum Framework contains a number of essential learning areas. Each is divided into learning strands, which are fundamentally the same as the Attainment Targets in Baker's 1988 model. Each strand is sub-divided into eight sequential levels, expressed in the form of achievement objectives (often three or four per level). While content is not rigidly stipulated in the New Zealand model in the same way as in the English and Welsh programmes of study, it is clear that these curricula are fundamentally very similar. Scotland provides a further example of this curriculum homogeneity. The 5-14 Framework has levels (six instead of eight), is divided into attainment outcomes and strands, and like its cousins in England and Wales, and in New Zealand, is articulated through the use of outcomes. Again while there are differences, the overall picture is one of similarity, of policy migration, and homogeneity of provision.

Further similarities can be discerned in the assessment trends that have accompanied initiatives in the area of vocational education and training. Again, there is considerable evidence of policy migration, as Jessup's (1990) competency-based model has appeared in different forms in various parts of the globe. Thus we have seen the development of NVQs in England and Wales, and the partial extension of the competency-based model to the GNVQ initiative, which was designed to bridge the academic-vocational divide. In Scotland there was the development of the SCOTVEC framework. This, combined with the subsequent transplanting of the model wholesale into the New Zealand context (Irwin 1994; Smithers 1997), where the intention was to use the model for the assessment of all qualifications, including school-based academic accreditation, and further migration 
to South Africa (Jansen 1999), is indicative of the tendency for curriculum development to be subject to global policy migration trends.

The structure and lexicon that are common to each of the above curricula, can be viewed as one manifestation of the direct or primary influence of globalization mentioned previously. As already noted, educational reform has been accompanied by a fundamental change in the discourses that frame education. Such discourses reflect the new dominance of the lexicon of business within education, and of managerial forms of control from a distance, such as those that are manifest in the management of transnational corporations. They are inherent in curricula that utilise teleological outcomes, and the language of performativity. The influence of human capital theory is manifest within the structure of the vocational curricula; performance criteria, and a linear, atomized approach to learning are characteristic of the same philosophies that have been so decisively promulgated by organisations like the World Bank, the IMF and the OECD.

A second manifestation of the influence of globalization is secondary or indirect in nature. It is largely apparent in the assertion of central control over education. Smyth and Shacklock (1998:17) have noted the manner in which teaching has been 'structurally adjusted to accommodate to these global pressures'. This has been achieved by what they describe as:

a dramatic shift in the boundaries of control, from direct, overt and bureaucratic forms of surveillance, to more covert forms that take expression in the way work itself is structured.

This statement raises a number of interesting issues. First, it is clear that teaching, like industry, is becoming subject to technical rational forms of managerialism, first and foremost being the definition or prespecification of roles and work through the use of performance 
criteria. This is evident in both the outcomes that teachers have to now demonstrate within their own work and in the forms of curriculum that have been imposed centrally and which were discussed above. In all of this, it is possible to discern the influence of globalization, and the pressure that this has placed upon the modern nation state. Centralism has emerged at least in part as a consequence of seemingly contradictory internal pressures which can be linked to globalization.

The first of these manifests itself as a reaction against globalization, and a process of national reconstruction through curriculum prescription. The English/Welsh National Curriculum, with its 'consistent requirement that schools concentrate on British History, British Geography and 'classic' English literature' is about 'creating, or recreating ... national identity' (Power and Whitty 1999: 20). As such, it is a good example of curriculum development being linked to the re-assertion of national sovereignty, local heterogeneity in the face of globalization. In the case of England and Wales, it is most certainly the product of neo-conservative elements within the government of the time, and it seems certain that it resulted from the victory within the Conservative Party of this group following policy struggles with the neo-liberal wing of the party (Ball 1990; Lawton 1994). According to Goodson:

the balance of subjects in the national curriculum suggests that questions of national identity have been preeminent, rather than industrial or commercial requirements (1990: 221).

There is clearly a case for asserting that the predominance of this policy wing of the Tory party is at least in part due to "a general sense of the nation state being in economic decline and subject to globalization and to amalgamation in the wider European community" (Goodson 1995: 205). 
While other national curricula have been less aggressive in the pursuit of national identity than the English/Welsh variant, there remain nevertheless clear indications that policy has been driven by similar considerations in other countries. For instance New Zealand's Curriculum Framework places great emphasis on New Zealand society and culture (Ministry of Education 1993), and there is a corresponding importance granted to promoting Scottish issues in the newly revised 5-14 Curriculum (Scottish Executive 2000). It can be seen that at least an element of curriculum policy across the anglophone states can be viewed in such terms as a nationalistic reaction to the perceived threats posed by globalization

The second can be seen more as a response to globalization. It is the perceived need for governments to respond in the face of economic threats and a belief that education can provide the solution to these threats. It can be seen in neo-liberal economic terms, and is perhaps globally more significant than the forms of nationalist reaction described above. Dale (1999: 4) argues that the clearest effects of globalization on education policy come from the consequences of states' reorganisation of their priorities to make them more competitive'. Gough (1999: 77) has argued similarly that the Victoria State Curriculum and Standards Framework in Australia can be understood as a product of a centralising tendency in educational restructuring that has been animated by economic globalization'. It can be seen that, 'given the increasing limitations on individual nation states to control the terms of economic competition, they have had to look to their own institutions and human resources to meet the challenge of economic competition' (Brown and Lauder 1992: 4). Education as a controllable state function has thus been a political tool for achieving this objective, and corollary of this has been curriculum development cast in teleological terms, as a means of 'preparing young people to function as productive members of our society' (Taba, cited in Fry 1985: 5). 
The development of a vocational pathway in English and Welsh education is another example of this tendency; again reaction to globalization has played key role in the development of policy. Ball has described the 'new vocationalism', which gives voice to the industrial trainers, although at least in the case of Tory administrations these groups have been less powerful than the neo-conservative interests that promoted the National Curriculum (Ball 1990. Also see Brown and Lauder 1992; Lawton 1994; Halsey et al 1997). NVQs and GNVQs have been predicated on a perception that Britain needs to 'upskill' its workforce if it is to survive in the global marketplace; moreover these perceptions are not confined to the area of Vocational Education and Training. The apparent continuation of neo-liberal strands of Conservative policy by New Labour (Power and Whitty 1999), for example the setting up and continuation of the specialist schools programme, could be said to have been motivated by similar concerns. This perception has been accompanied by a corresponding and less tenable belief that educational standards have declined, and that this is responsible for economic crisis and an inability to compete internationally - a view characterized by intellectual poverty and a paucity of empirical support' (Brown and Lauder 1992: 24).

\section{CONCLUSION}

Globalization has clearly had a major impact on the education systems of Anglophone nations. This impact has a dual nature. First we can discern a direct or primary impact of globalisation. This is apparent in the predominance of a new global vocabulary of education, as the international discourses of business have penetrated deeply into the world of education, in many respects even supplanting the more traditional educational lexicon. It is also apparent in the current fad for marketisation of education, in common with many other public services, and the withdrawal of government from the responsibility for 
administration of these services, whilst maintaining control from a distance. Dale's 'hollowing out' metaphor (Dale 1997: 274), whereby the state retains many powers, despite divesting itself of much of the responsibility for administration, is most apposite in describing this latter trend.

The second side of the paradox of globalization is the indirect or secondary impact that the phenomenon has exerted on education systems. This influence is twofold. This dual tendency is apparent in what I have called reaction against: the nation building attempts of the architects of national curricula, as the burden of reinvented tradition is placed, like most other social burdens, on the shoulders of education' (Hargreaves 1994: 55). It is also apparent in what I have termed response to: the tendencies towards using schools to solve the economic problems of the nation, through trends such as the 'new vocationalism' (although one is allowed to smile wryly at Torrance's observation that if we are worried about contemporary economic performance, isn't it the educational standards of ten or twenty years ago that should be the focus of our concern' (Torrance 1992: 164)).

Of course, globalization is not the only factor behind the changes that are affecting education, and likewise it is not the only factor that motivates the local interest groups that formulate policy. One must bear in mind Hargreaves' warning: 'multi-causality, pluralistic conflict, administrative complexity and historical inertia' - all have an impact on the policy making process (Hargreaves 1983: 49). Nevertheless globalization has posed challenges of a hitherto unknown nature to nation states, and much of the seemingly recent, never-ending change in education is a corollary of these challenges.

\section{REFERENCES}

Apple, M. (1990). Ideology and Curriculum. London: Routledge Apple, M. (1995). Education and Power. London: Routledge 
Apple, M. (1998). Knowledge, Pedagogy and the Conservative Alliance. In Studies in the Literary Imagination, Spring 98, Vol.31/1, 5-19

Apple, M. (1999). Rhetorical Reforms: markets, standards and inequality. In Current Issues in Comparative Education (online), 1/2, http://www.tc.columbia.edu/cice/

Arnold, M. (1996). The High Tech Fordist School. In Interchange, 27/3 \& 4, 225-50

Ball, S. J. (1990). Politics and Policy Making in Education. London: Routledge

Ball, S. J. (1997). Good school/bad school: paradox and fabrication. In British Journal of Sociology of Education, 18/3, 317-36

Ball, S.J. (1998). Big Policies/Small World: an introduction to international perspectives in education policy. In Comparative Education, 34/2, 119-130

Beattie, N. (1990). The wider context: are curricula manageable? In T. Brighouse and B. Moon (eds.). Managing the National Curriculum: some critical perspectives. London: Longman

Bernstein, B. (1990). The Structuring of Pedagogic Discourse: class codes and control, Vol. 4. London: Routledge

Blenkin, G. M., Edwards, G. and Kelly, A. V. (1992). Change and the Curriculum. London: Paul Chapman Publishing

Brown, P. and Lauder, H. (eds.) (1992). Education for Economic Survival: from Fordism to post-Fordism. London: Routledge

Brown, P. and Lauder, H. (1996). Education, Globalization and Economic Development. In A. H. Halsey, H. Lauder, P. Brown and A. S. Wells (eds.) (1997). Education, Culture, Economy and Society. Oxford: Oxford University Press

Clarke, J., Cochrane, A. and McLaughlin, E. (1994). Why management matters. In: J. Clarke, A. Cochrane and E. McLaughlin (eds.). Managing Social Policy, 1-12. London: Sage

Codd, J., (1999). Educational Reform, Accountability and the Culture of Distrust. In New Zealand Journal of Education Studies, 34/ 1, 45-53

Cox, R.W. (1995). Critical Political Economy. In B. Hettne. International Political Economy. London: Zed Books

Cox, R.W. (1996). Approaches to World Order. Cambridge: Cambridge University Press

Dale, R. (1997). The State and the Governance of Education: an analysis of the restructuring of the state-education relationship. In A. H. Halsey, H. Lauder, P. Brown and A. S. Wells (eds.). Education, Culture, Economy and Society. Oxford: Oxford University Press 
Dale, R. (2000). Globalization: A New World for Comparative Education. In J. Schriewer (ed.). Discourse Formation in Comparative Education. Frankfurt: Peter Lang

Department of Education (1988). Tomorrow's Schools: the reform of education administration in New Zealand. Wellington: Department of Education

Edwards, R., Nicoll, K. and Tait, A. (1999). Migrating metaphors: the globalization of flexibility in policy. In the Journal of Education Policy, 14/6, 619-630

Edwards, R. and Usher, R. (1997). Final Frontiers? Globalization, Pedagogy and (Dis)location. In Curriculum Studies, 5/3, 253-267

Elliott, J. (1998). The Curriculum Experiment: meeting the challenge of social change. Buckingham: Open University Press

Falk, R. (1999). Predatory Globalization: a critique. Cambridge: Polity Press

Fry, R. (1985). It's Different for Daughters: a history of the curriculum for girls in New Zealand Schools. Wellington: New Zealand Council for Educational Research

Gibson, R. (1986). Critical Theory and Education. London: Hodder and Stoughton

Giddens, A. (1990). The Consequences of Modernity. Stanford University Press: Stanford

Girwitz, S., Ball, S. J. and Bowe, R. (1995). Markets, Choice and Equity in Education. Buckingham: Open University Press

Goodson, I. F. (1990). Nations at risk and national curriculum: ideology and identity. In Politics of Education Association Yearbook, 219-52. London: Taylor and Francis

Goodson, I.F., (1995), The Making of Curriculum: some collected essays, London, The Falmer Press

Gough, N. (1999). Globalization and school curriculum change: locating a transnational imaginary. In the Journal of Education Policy, $14 / 1,73-84$

Green, A. (1999). Education and globalization in Europe and East Asia: convergent and divergent trends. In the Journal of Education Policy, 14/1, 55-71

Habermas, J. (1976). Legitimation Crisis. London: Heinemann

Halsey, A.H., Lauder, H., Brown, P. and Wells, A.S. (eds.) (1997). Education, Culture, Economy and Society. Oxford: Oxford University Press 
Hargreaves, A (1983). The Politics of Administrative Convenience. In J. Ahier and M. Flude (eds.). Contemporary Education Policy. Beckenham: Croom Helm

Hargreaves, A. (1994). Changing Teachers, Changing Times: teachers' work and culture in the post-modern age. London: Cassell

Helsby, G. (1999). Changing Teachers' Work. Buckingham: Open University Press

Henry, M., Lingard, B., Rizvi, F. and Taylor, S. (1999). Working with/against globalization in education. In the Journal of Education Policy, 14/1, 85-97

Hood, C. (1995). Contemporary Public management: a new global paradigm? In Public Policy and Administration, 10/2, 104-117

Irwin, M. (1994). Curriculum, assessment and qualifications: an evaluation of current reforms. Auckland: Education Forum

Jansen, J.D. (1999). Globalization, curriculum and the third world state. In Current Issues in Comparative Education (online), 1/2, http://www.tc.columbia.edu/cice/

Jessup, G. (1991). Outcomes: NVQs and the Emerging Model of Education and Training. London: Falmer Press

Kelly, A. V., (1989). The Curriculum: Theory and Practice. London: Paul Chapman Publishing

Kumar, K. (1992). New Theories of Industrial Society. In P. Brown and H. Lauder (eds.). Education for Economic Survival: from Fordism to post-Fordism. London: Routledge

Lawton, D. (1994). The Tory Mind on Education, 1979-1994. London: The Falmer Press

Levin, B. (1998). An Epidemic of Education Policy: (what) can we learn from each other? In Comparative Education, 34/2, 131-141

Macedo, D. (1994). Literacies of Power: what Americans are not allowed to know. Boulder, CO: Westview Press

Marginson, S. (1999). After globalization: emerging politics of education. In the Journal of Education Policy, 14/1, 19-31

Ministry of Education (1993). The New Zealand Curriculum Framework. Wellington: Learning Media

O'Neill, A. M. (1996/97). Curriculum Reform: Development Issues in Aotearoa New Zealand. In Delta: Policy and Practice in Education, 48/2, 49/1, 127-140

Picot, B. (1988). Administering for Excellence: effective administration in education: report of the Taskforce to Review Educational Administration. Wellington: The Taskforce

Power, S. and Whitty, G. (1999). Market Forces and School Culture. In 
J. Prosser (ed.). School Culture. London: Paul Chapman Publishing

Power, S. and Whitty, G. (1999). New Labour's education policy: first, second or third way? In the Journal of Education Policy, 14/2, 535546

Reich, R. (1991). Why the rich are getting richer and the poor, poorer. In A. H. Halsey, H. Lauder, P. Brown and A. S. Wells (eds.) (1997). Education, Culture, Economy and Society. Oxford: Oxford University Press

Reich, R. (1992). The work of nations: preparing ourselves for $21^{\text {st }}$ century capitalism. London: Simon and Schuster

Scottish Executive (2000). The Structure and Balance of the Curriculum: 5-14 Guidelines. Edinburgh: Learning and Teaching Scotland

Skilbeck, M. (1990). Curriculum Reform: an overview of trends. Paris: OECD

Smithers, A. (1997). The New Zealand Qualifications Framework. Auckland: Education Forum

Smyth, J. and Shacklock, G. (1998). Re-Making Teaching: ideology, policy and practice. London: Routledge

Stenhouse, L. (1975). An introduction to curriculum research and development. London: Heinemann Educational

Torrance, H. (1992) Educational Assessment and Educational Standards: towards and alternative view of quality. In P. Brown and H. Lauder (eds.). Education for Economic Survival: from Fordism to post-Fordism. London: Routledge

Whitty, G., Power, S. and Halpin, D. (1998). Devolution and Choice in Education: The School, the State and the Market. Buckingham: Open University Press

Wiseman, J. (1995). Globalisation is not Godzilla. Frontline, 26 (July), 5-6 